\title{
Co-expression networks identify distinct immune infiltrates in hepatocellular carcinoma
}

\author{
Derek Y Chiang ${ }^{*}$, Alan Huang \\ From 30th Annual Meeting and Associated Programs of the Society for Immunotherapy of Cancer (SITC 2015) \\ National Harbor, MD, USA. 4-8 November 2015
}

\section{Background}

The vast majority of hepatocellular carcinoma (HCC) arise in the context of chronic inflammation, especially with hepatitis B or hepatitis $C$ viral infection. Several studies have identified prognostic immune biomarkers in HCC tumors and peritumoral regions. Recently, a Phase 1 trial of a PD-1 inhibitor has demonstrated efficacy in HCC. In order to characterize the diversity of immune microenvironments in HCC, we investigated co-expression networks of immune lineage-specific genes.

\section{Results}

We conducted a meta-analysis of gene expression data from over $500 \mathrm{HCC}$ tumors and matched adjacent liver specimens. PD-L1 and PD-L2 had higher RNA levels in adjacent liver, compared with tumors. Tumoral expression of PD-L1 and PD-L2 were correlated with macrophage lineage genes. We identified 3 major co-expression network modules that corresponded with different immune cell sub-types: (1) An infiltrating T cell module was enriched for TCR activation, recruitment chemokines and elevated immune checkpoints. (2) A hepatic stellate cell module was associated with extracellular matrix remodeling, epithelial-to-mesenchymal transition and TGF-beta signaling. (3) A macrophage module had elevated macrophage lineage genes. By integrating these co-expression modules with HCC molecular sub-classes, the infiltrating $\mathrm{T}$ cell signature was enriched in the Hoshida $\mathrm{S} 1$ subclass $^{1}$ and Chiang interferon subclass ${ }^{2}$, and was less prevalent among HCC with CTNNB1 mutations.

\section{Conclusion}

Transcriptomic analyses revealed immune cell types and potential regulators in HCC. The joint profiling of

Novartis Institutes for Biomedical Research, Cambridge, MA, USA infiltrating immune sub-types and genetic alterations may guide the selection of combination therapies.

Published: 4 November 2015

\section{References}

1. Hoshida Y, et al: Cancer Research 2009, 69:7385-7392

2. Chiang DY, et al: Cancer Research 2008, 68:6779-6788.

\section{doi:10.1186/2051-1426-3-S2-P213}

Cite this article as: Chiang and Huang: Co-expression networks identify distinct immune infiltrates in hepatocellular carcinoma. Journal for ImmunoTherapy of Cancer 2015 3(Suppl 2):P213.
Submit your next manuscript to BioMed Central and take full advantage of:

- Convenient online submission

- Thorough peer review

- No space constraints or color figure charges

- Immediate publication on acceptance

- Inclusion in PubMed, CAS, Scopus and Google Scholar

- Research which is freely available for redistribution
() Biomed Central 